\title{
Urinary incontinence in female road runners from the Brazilian Federal District - occurrence and associated risk factors
}

\author{
Incontinência urinária em grupos de corredoras de rua no Distrito Federal - prevalência e \\ fatores associados
}

\section{A incontinência urinaria en grupos de corredoras de la calle en el Distrito Federal - prevalencia y factores associados}

Amirni Vieira Almeida ${ }^{a}$ (D) Carina de Sousa Freitas Santos ${ }^{b}$ (D) , Marianna Vale D’Alessandro Barbosa ${ }^{c, *}$ (D), Aline Teixeira Alves ${ }^{c}$ (D), Elizabeth Rideko Imoto $^{b}$ (D), Viviane Tobias Albuquerque ${ }^{b}$ (D)

\section{Keywords}

Urinary incontinence; Urinary incontinence stress;

Female runners;

Prevalence.

\section{Palavras-chave} Incontinência urinária; Incontinência urinária de esforço; Corredoras de rua; Prevalência.

\section{Palabras clave} Incontinencia urinaria; Incontinencia urinaria de esfuerzo; Corredoras de la calle; Prevalencia.

\begin{abstract}
Urinary incontinence (UI) is defined as the involuntary leakage of urine and stress urinary incontinence (SUI) is a common type of UI, characterized by the loss of urine during physical effort, including running. Objective: Analyze UI and associated factors in female road runners in the Brazilian Federal District (DF). Method: Cross-sectional descriptive study that investigated UI by applying an adapted questionnaire to female road runners in DF. Results: 94 runners, 3.2\% of whom reported UI and 56.6\% complained of SUI. Body mass index (BMI), birth weight of largest baby and episiotomy were factors associated of SUI. Conclusion: Although few women reported UI while running, the results suggest that SI needs to be addressed, especially when associated with risk factors.
\end{abstract}

\section{RESUMO}

A incontinência urinária (IU) é definida como a perda involuntária de urina, e a incontinência urinária de esforço (IUE) é um tipo comum de perda urinária, caracterizada pela perda de urina durante esforço físico, como, corrida. Objetivo: Analisar a prevalência e fatores associados de IU em corredoras de rua do Distrito Federal (DF). Método: Estudo transversal descritivo, com aplicação de questionário adaptado, em mulheres, corredoras no DF. Resultados: De 94 corredoras, 3.2\% apresentaram IU, sendo IUE, 56.6\% mais comum entre 40 a 49 anos. Índice de massa corporal (IMC), peso do maior bebê e episiotomia foram fatores associados à IU. Conclusão: Embora poucas mulheres relatem IU, os resultados sugerem que a IU precisa ser abordada, ainda quando associada aos fatores de risco.

\begin{abstract}
RESUMEN
La incontinencia urinaria (IU) se define como la pérdida perdida involuntaria de orina, y la incontinencia urinaria de esfuerzo (IUE) es un tipo común de pérdida urinaria, caracterizada por la pérdida de orina durante el esfuerzo fisico, como correr. Objetivo: Analizar la prevalencia y sus factores asociados de IU en corredoras de la calle en el Distrito Federal (DF). Método: Estudio descriptivo de corte transversal, com aplicación de un cuestionario adaptado, en mujeres, en DF. Resultados: De 94 corredoras, 3.2\% tenían UI, con IUE más común entre 40 y 49 años. Índice de masa corporal (IMC), partos de fetos grande y la episiotomía fueros factores associados con la IU. Conclusión: Aunque pocas mujeres informan IU, los resultados sugieren que es necesario abordar la IU, incluso cuando se associa com factores de riesgo.
\end{abstract}




\section{INTRODUCTION}

According to the International Continence Society (ICS), urinary incontinence (UI) is defined as complaint involuntary loss of urine and stress incontinence (SUI) involuntary loss of urine on effort or physical exertion or on sneezing or coughing (Haylen et al., 2010). The prevalence of UI increases with advancing age. Symptoms of UI in women have been linked to several risk factors, age, obesity, parity, pregnancy, vaginal delivery, chronic obstructive pulmonary disease, gynecological surgeries, diet, smoking, comorbidities, and physical exercise (Pedersen et al., 2017; Nygaard and Shaw, 2016).

With the increase in the practice of sports and the awareness of the importance of physical activity, there has been a growth in pelvic floor dysfunction in practitioners of physical activity in both professional and amateur athletes. In a systematic review, when compared to about the other 17 sports, the prevalence ranged from $5 \%$ in low-impact activities to $80 \%$ in activities such as jumping on a trampoline. The amount of training also proved to be a factor in the development of UI in athletes. Teixeira et al. (2018) observed the presence of $36 \% \mathrm{UI}$ in athletes, and when compared to sedentary women, athletes had a $177 \%$ higher risk of presenting UI (Mattos et al., 2018; Teixeira et al., 2018).

Urinary incontinence is a major public health problem and is associated with poor quality of life (QOL). High age and body mass index (BMI) associated with highimpact physical activity were positive associations with the reduction in quality of life in athletes with urinary symptoms. Meanwhile, higher values of maximum voluntary contraction of the pelvic floor muscles (PFM) and longer physical activity were associated with improved QOL and reduced urinary symptoms. In female athletes, UI leads to reduced performance, change of sport, and even avoid physical activity (Pizzol et al., 2021; Pires et al., 2020; Casey and Temme, 2017).

Regarding the current evidence, it is known that running is a sport with intense involuntary activation of PFM. However, the mechanism of activation of such muscles during physical activity is still uncertain. Besides, there are still some doubts about the practice of long-term physical exercise and strenuous exercise in the support and function of PFM. The intra-abdominal pressure and the pressure in the PFM vary depending on the type of sport and each woman. Also, it is not yet known what the limits of values that can cause dysfunctions or benefits for this musculature are (B $\varnothing$ and Nygaard, 2020; Moser et al., 2018; Shaw and Nygaard, 2017).

Running involves global muscle activation, including the pelvic floor (PFMs) and abdominal muscles, being the latter also indirectly related to PFM support (Leitner et al., 2017). In a cross-sectional study by Forner and collaborators, when comparing the symptoms in the PFMs in female runners with Crossfit practitioners, they observed that runners had a higher prevalence of pelvic organ prolapse and anal incontinence. SUI was present in both groups. However, it was not found a significant difference $37 \%$ in runners and $41 \%$ in Crossfit practitioners) female runners who have already had vaginal birth reported more symptoms in the PFMs (Forner et al., 2021).

Taking into account the high prevalence of UI in athletes and its negative impact on QOL, this study aims to investigate UI and associated factors in female road runners from the Federal District (DF) in Brazil.

\section{METHODS}

This is a cross-sectional descriptive study with female road runners from DF, recruited during road races. Inclusion criteria were being a woman, aged between 18 and 49 years, and member of a running club or group in the Federal District. Women with physical disabilities, professional athletes and those who had undergone gynecological surgeries, were pregnant or had been clinically diagnosed with UI were excluded.

Female runners who met the inclusion criteria were invited to participate, advised of the study objectives and methodology and provided written informed consent. Sociodemographic and clinical data were initially assessed, followed by a self-administered questionnaire designed by the researchers, containing 16 objective and 5 subjective questions. Adaptations of the question "Do you worry in case you smell?" from the King's Health Questionnaire (KHQ) (Fonseca et al., 2005) and a question on the type of UI from the International Consultation on Incontinence Questionnaire - Short Form" (ICIQ-SF) (Tamanini et al., 2004) were also included.

The study was approved by the Unieuro Research Ethics Committee (REC), under protocol number 2.210.208.

Data were analyzed using SPSS software, version 22.0. Descriptive statistics were used to characterize the sample according to mean, standard deviation and frequency. The chisquared test was used to analyze categorical data, the relationship between running and $\mathrm{UI}$, and between age, BMI and running time. Significance was set at less than or equal to 0.05 .

\section{RESULTS}

From October to November 2017, 190 runners from 16 running clubs in DF were contacted, but 45 declined to participate and 32 were older than 49 years. Of the 113 women remaining, 19 were excluded due to a clinical diagnosis of urinary incontinence (4), previous gynecological surgery (14) or pregnancy (1), for a final sample of 94 runners.

The predominant age range was 30 to 39 years $(45.7 \%)$, with an average age of $34.63 \pm 6.85$ years. Sixty-two participants (66\%) reported they had a college degree or diploma, and $60.6 \%$ were classified as normal weight based on $\mathrm{BMI}$. With respect to their obstetric profile, $47.9 \%$ (45) had one or more children, $62.2 \%$ (28) 
had undergone a Cesarean section and $26.7 \%$ (12) vaginal delivery, and $73.3 \%$ reported that the birth weight of their largest baby was less than $3.8 \mathrm{~kg}$. Seventeen runners (58.8\%) who had at least one vaginal delivery reported that episiotomy was performed.

In regard to weekly training time, $80.8 \%$ (76) reported $<7$ hours a week and $19.2 \%$ (18) $>7$ hours. Thirty-nine women had been running for less than 12 months and 39 between 12 months and 5 years (Table 1 ).

In terms of clinical characteristics, $72.30 \%$ (68) do not experience urinary urgency while running, $95.70 \%$ (90) are capable of holding urine in while running, 3.20\% (3) leak urine when running and 16\% (15) worry about the smell of urine after a run.

Although only 3 women said they leaked urine while running, positive answers were given in relation to the type of urine loss. For the question "When do you leak urine?", the most prevalent type was SI at $56.6 \%$ (17), assessed by the items "coughing/sneezing" and/ or "during exercise". Responses to the item "before I get to the bathroom" suggest the presence of urge incontinence in $13.3 \%$ (4). An association was observed between items related to stress and urge incontinence in $10.0 \%$ (3); $13.3 \%$ (4) experienced leakage "after urinating, when I'm already dressed"; 3.3\% (1) reported nocturnal enuresis (bedwetting) based on the item "when I'm sleeping"; "leaks for no obvious reason" represented 3.3\% (1) and "leaks all the time" was not marked by any participants (Table 2).

Analysis of the relationship between possible risk factors and the self-reported type of UI in runners demonstrated that episiotomy was significantly related to SI $(p=0.01)$. Birth weight of the largest baby showed a statistically significant relation $(p=0.05)$ to $S I$, whereby all the runners with this complaint had delivered babies weighing more than $3.8 \mathrm{~kg}$ (3). Body mass index (BMI) exhibited a statistically significant association with UI $(p<0.01)$, which was more prevalent in overweight (12) and obese runners (5). There was no statistically significant correlation between $U I$ and age $(p=0.27)$, parity $(p=0.50)$ or type of delivery $(p=0.50)$; however, urine leakage tended to rise with increased age. Although urine loss was not associated with weekly training time $(p=0.78)$, it was related to how long participants had been involved in the sport (in years) $(p=0.05)$, whereby the less time they had been involved in running, the greater the urine leakage. There was a direct correlation between "urinary urgency while running" and UI ( $p=0.02)$ (Table 3$)$.

Table 4 shows the results of analyses of the relationship between age, $\mathrm{BMI}$, time involved in running and urinary urgency during running. Both BMI and urinary urgency when running were greater in women who had been involved in the sport for less time.

Participants' knowledge regarding physiotherapy to prevent or treat urine leakage was not related to UI
Table 1. Sociodemographic characteristics of runners from DF.

\begin{tabular}{|c|c|c|}
\hline Variable & $\mathrm{n}=94$ & $\begin{array}{c}\text { Percent- } \\
\text { age } \%\end{array}$ \\
\hline \multicolumn{3}{|l|}{ Age } \\
\hline 18 to 29 years & 12 & $12.8 \%$ \\
\hline 30 to 39 years & 43 & $45.7 \%$ \\
\hline 40 to 49 years & 39 & $41.5 \%$ \\
\hline \multicolumn{3}{|l|}{ Schooling Level } \\
\hline High School Diploma & 7 & $7.4 \%$ \\
\hline Incomplete University & 2 & $2.1 \%$ \\
\hline Complete University & 62 & $66 \%$ \\
\hline Graduate degree (lato sensu) & 15 & $16 \%$ \\
\hline Graduate degree (stricto sensu) & 8 & $8.5 \%$ \\
\hline \multicolumn{3}{|l|}{ BMI } \\
\hline Normal weight $18.5-24.99 \mathrm{~kg} / \mathrm{cm}^{2}$ & 57 & $60.6 \%$ \\
\hline Overweight $25-29.99 \mathrm{~kg} / \mathrm{cm}^{2}$ & 30 & $31.9 \%$ \\
\hline Obese $30 \mathrm{~kg} / \mathrm{cm}^{2}$ or more & 7 & $7.4 \%$ \\
\hline \multicolumn{3}{|l|}{ Parity } \\
\hline No children* & 49 & $52.1 \%$ \\
\hline 1 & 18 & $19.10 \%$ \\
\hline 2 & 20 & $21.3 \%$ \\
\hline 3 & 7 & $7.4 \%$ \\
\hline Type of delivery & $\mathrm{n}=45$ & \\
\hline Cesarean & 28 & $62.2 \%$ \\
\hline Vaginal & 12 & $26.7 \%$ \\
\hline Both & 5 & $11.1 \%$ \\
\hline Birth weight of largest baby & $\mathrm{n}=45$ & \\
\hline$<3.8 \mathrm{~kg}$ & 33 & $73.3 \%$ \\
\hline$<3.8 \mathrm{~kg}$ & 12 & $26.7 \%$ \\
\hline Episiotomy & $\mathrm{n}=17$ & \\
\hline No & 7 & $41.2 \%$ \\
\hline Yes & 10 & $58.8 \%$ \\
\hline \multicolumn{3}{|l|}{ Time involved in the sport } \\
\hline Up to 1 year & 39 & $41.49 \%$ \\
\hline 1 to 5 years & 39 & $41.19 \%$ \\
\hline 5 to 10 years & 12 & $12.77 \%$ \\
\hline 10 to 15 years & 3 & $3.19 \%$ \\
\hline Information not provided & 1 & $1.06 \%$ \\
\hline \multicolumn{3}{|l|}{ Weekly training time } \\
\hline$<7$ hours per week & 76 & $80.8 \%$ \\
\hline$>7$ hours per week & 18 & $19.2 \%$ \\
\hline
\end{tabular}

$\mathrm{n}$ : sample size; BMI: body mass index $\left(\mathrm{kg} / \mathrm{cm}^{2}\right)$.

( $p=0.65)$, but $48.9 \%$ (46) were not aware of it, while $51.1 \%$ (48) knew about pelvic physical therapy.

There was no significant difference in urine leakage when a physical therapist was employed by the running club ( $p>0.09$ ); Ul was reported by $31.8 \%$ (14) of women from clubs with a physical therapist and $32.0 \%(16)$ in those without one. 


\section{DISCUSSION}

This study aimed to investigate $\mathrm{UI}$ and associated factors in groups of road runners from the Brazilian Federal District and found that although 3\% reported urine loss while running, $56.6 \%$ stated that the most common form of leakage is SI. Risk factors such as episiotomy, birth weight of the largest baby, and high BMI showed a positive association with the type of UI most reported by participants (SI). The prevalence of SUI in our study was quite high, which confirmed the findings of other authors. Abitteboul et al. (2015) analyzed 517 nonprofessional (amateur) runners, as in this study, through the application of a questionnaire in France and found a

Table 2. Clinical characteristics related to urinary symptoms while running.

\begin{tabular}{lcc}
\hline \multicolumn{1}{c}{ Variable } & $\mathbf{n = 9 4}$ & Percentage \% \\
\hline Urinary urgency while running & & \\
No & 68 & $72.30 \%$ \\
Yes & 26 & $27.70 \%$ \\
Holding urine in while running & & \\
No & 4 & $4.30 \%$ \\
Yes & 90 & $95.70 \%$ \\
Urine loss while running & & \\
No & 91 & $96.80 \%$ \\
Yes & 3 & $3.20 \%$ \\
Concern about the smell of & & \\
urine after running & & \\
No & 79 & $84 \%$ \\
Yes & 15 & $16 \%$ \\
Types of UI & & \\
Stress incontinence & 17 & $56.6 \%$ \\
Urge incontinence & 4 & $13.3 \%$ \\
Stress and urge incontinence & 3 & $10.0 \%$ \\
Post-micturition dribble (PMD) & 4 & $13.3 \%$ \\
Bedwetting & 1 & $3.3 \%$ \\
No obvious reason & 1 & $3.3 \%$ \\
\hline N Sample size; Ul: urinary incontinence
\end{tabular}

$\mathrm{n}$ : sample size; UI: urinary incontinence. prevalence of $30.7 \% \mathrm{UI}$ in any circumstance and $52.9 \%$ presented SUI only during the running. Another study compared the dysfunctions of PFMs in non-professional athletes, practitioners of various sports with nonathletes. It reported the occurrence of sexual symptoms and loss of flatus in both groups, but with no significant difference. But it concluded that amateur athletes are 3 times more likely to develop UI, SUI being the most common when performing high impact activities. In other impact sports SUI is also present. Amateur and professional volleyball players showed a rate of $55.6 \%$ and $50 \%$, respectively. However, the amount of urine loss in grams was significantly higher in professional athletes (Abitteboul et al., 2015; Almeida et al., 2016).

The results here obtained corroborate to those reported in the literature, with SI prevalent in 56.6\% of the sample studied, suggesting that running may be an important factor in the development of stress incontinence, although only $3 \%$ reported urine loss

Table 3. Relationship between road running and UI.

\begin{tabular}{lccc}
\hline & $\begin{array}{c}\text { Continent } \\
\mathbf{n}(\%)\end{array}$ & $\begin{array}{c}\text { Incontinent } \\
\mathbf{n}(\%)\end{array}$ & $\mathbf{p}$-value \\
\hline Weekly training time & & & $\mathbf{p}=\mathbf{0 . 7 8}$ \\
$<7$ hours per week & $51(67.1 \%)$ & $25(32.9 \%)$ & \\
$>7$ hours per week & $13(72.2 \%)$ & $5(27.8 \%)$ & \\
Time involved in the & & & $\mathbf{p}=\mathbf{0 . 0 5}$ \\
sport & $24(61.5 \%)$ & $15(38.5 \%)$ & \\
Up to 1 year & $27(69.2 \%)$ & $12(30.8 \%)$ & \\
1-5 years & $9(75 \%)$ & $3(25 \%)$ & \\
5-10 years & $3(100 \%)$ & $0(0.0 \%)$ & \\
10-15 years & $1(100 \%)$ & $0(0.0 \%)$ & \\
Information not & & & $\mathbf{p}=\mathbf{0 . 0 2}$ \\
provided & & & \\
Urinary urgency while & & & \\
running & $51(75 \%)$ & $17(25 \%)$ & \\
No & $13(50 \%)$ & $13(50 \%)$ & \\
Yes &
\end{tabular}

Chi-squared test $n \%$ : percentage of the sample $p \leq 0.05$.

Table 4. Relationship between time involved in the sport and age, BMI and urinary urgency while running.

\begin{tabular}{|c|c|c|c|c|c|c|}
\hline & Up to 1 year & 1 and 5 years & 5 to 10 years & 10 to 15 years & $\begin{array}{l}\text { Information not } \\
\text { provided }\end{array}$ & p-value \\
\hline & $\mathrm{n}(\%)$ & n (\%) & n (\%) & n (\%) & $\mathrm{n}(\%)$ & \\
\hline Age & & & & & & $p=0.12$ \\
\hline Group 1 (18 to 29 years) & $6(15.4 \%)$ & $6(15.4 \%)$ & $0(0.0 \%)$ & $0(0.0 \%)$ & $0(0.0 \%)$ & \\
\hline Group 2 (30 to 39 years) & $21(53.8 \%)$ & $12(30.8 \%)$ & $8(66.7 \%)$ & $1(33.3 \%)$ & $1(100 \%)$ & \\
\hline Group 3 (40 to 49 years) & $12(30.8 \%)$ & $21(53.8 \%)$ & $1(33.3 \%)$ & $2(66.7 \%)$ & $0(0.0 \%)$ & \\
\hline BMI & & & & & & $\mathrm{p}<0.01$ \\
\hline Normal & $17(43.6 \%)$ & $24(61.5 \%)$ & $12(100 \%)$ & $3(100 \%)$ & $1(100 \%)$ & \\
\hline Overweight & $16(41 \%)$ & $14(35.9 \%)$ & $0(0.0 \%)$ & $0(0.0 \%)$ & $0(0.0 \%)$ & \\
\hline Obese & $6(15.4 \%)$ & $01(2.6 \%)$ & $0(0.0 \%)$ & $0(0.0 \%)$ & $0(0.0 \%)$ & \\
\hline $\begin{array}{l}\text { Urinary urgency while } \\
\text { running }\end{array}$ & & & & & & $p=0.03$ \\
\hline No & $24(35.3 \%)$ & $31(45.6 \%)$ & $9(13.2 \%)$ & $3(4.4 \%)$ & $1(1.5 \%)$ & \\
\hline Yes & $15(57.7 \%)$ & $8(30.8 \%)$ & $3(11.5 \%)$ & $0(0.0 \%)$ & $0(0.0 \%)$ & \\
\hline
\end{tabular}

Chi-squared test $n \%$ : percentage of the sample $p \leq 0.05$. 
while running. This discrepancy may have occurred because participants were unaware of urine leakage or too embarrassed to report the problem. Other studies have demonstrated that physical activity can become a risk factor for urine leakage when not monitored by specialists and/or associated with other risk factors (Martins et al., 2017; Vasaghi-Gharamaleki and OstadRahimi, 2015; Silva et al., 2017).

According to several authors, age is one of the main risk factors for urinary incontinence. In the present study, age was not related to $\mathrm{UI}$, but its prevalence increased with age, affecting $41.5 \%$ of 40 to 49 -year-old subjects and corroborating the results of previous studies, in which the condition was more prevalent from the age of 40 years onwards (Mesquita et al., 2015; Silva et al., 2017; Henkes et al., 2015). In older adults, the disorder is due to the decline in estrogen levels and reduced vascularization that occur with aging, causing atrophy in PFM (Cândido et al., 2017).

Our study found no association between the type of delivery and urine loss. Still, $58.8 \%$ of the women who had a vaginal delivery (12 women) had an episiotomy. 2017 Cochrane review reinforces that the use of routine episiotomy should no longer be performed, as it increases, does not prevent, but rather raises the risk of severe perineal trauma and other complications compared to non-episiotomy. In other systematic reviews, episiotomy and severe perineal trauma increased the chance of muscle avulsion of the levator ani and enlarged the chance of injury to the anal sphincter by $30 \%$, seen through ultrasound images. When compared to the strength of PFMs in women who underwent cesarean section and the ones who had vaginal deliveries, there was no significant difference, demonstrating that the cesarean section was not a protective factor for the muscles. However, when compared to instrumental deliveries (forceps and episiotomy) with cesarean deliveries, the latter showed greater strength of PFMs. Also, women who had an episiotomy had more episodes of SUI three months after delivery when compared to women who had a vaginal delivery. These findings corroborate with our study, as the episiotomy rate was quite high, and nowadays, its damages to the PFM are widely known (Jiang et al., 2017; Lima et al., 2020; Driusso et al., 2020).

Besides the high rate of episiotomy as one of the causes of SUI in runners, $62.2 \%$ of women underwent cesarean delivery, as seen above. On the other hand, vaginal delivery compared to cesarean section did not show a significant difference in muscle strength, yet, it is still a quite controversial topic, as several studies demonstrate cesarean delivery as a factor associated with a lower rate of urinary incontinence and other PFM disorders. $52.1 \%$ of runners were nulliparous, corroborating to the findings of other authors in which the practice of a high-impact physical activity is a risk factor for developing SUI. Almousa et al. observed that SUI is one of the main dysfunctions that occur in nulliparous adolescents and middle-aged women, affecting between 1 and $42 \%$ of them. Among the risk factors, there are the BMI, the infant enuresis, and the high-impact physical activity (Blomquist et al., 2018; Keag et al., 2018; Novo et al., 2020; Almousa and van Loon, 2019)

In the present study, the birth weight of the largest baby was associated with $\mathrm{SI}$, which was present in all the runners with UI who had delivered babies weighing more than $3.8 \mathrm{~kg}$. This is in line with the findings of Nascimento et al. (2017) that found that changes in the womb during pregnancy combined with a large fetus influence the emergence of SI.

Another significant correlation observed here was the influence of maternal BMI on stress incontinence, which was more prevalent in overweight and obese runners. This corroborates with a systematic review with a meta-analysis conducted in 2018 that overweight women are $1 / 3$ more likely to have UI since when they are obese, the risk for dysfunction doubles. It also reported that the clinical advice for overweight and obese women should not only be based on metabolic damage but also on the information that the muscles will be overloaded and, consequently, weakened over time, causing greater chances of UI (Lamerton et al., 2018).

According to Filoni et al. (2015) an average of 7.77 hours of training a week was a risk factor for urine leakage, and the greater the duration and frequency of training, the more prevalent UI in high-impact sports athletes. However, this association was not observed in the present study. Martins et al. (2017) demonstrated that both the type of sport and training load influence urine leakage and that SI was more frequent in women with large training loads related to strenuous exercise (Filoni et al., 2015; Martins et al., 2017).

In our subjects, weight loss may have occurred as their time involved in the sport increased, resulting in less urine leakage, but the cross-sectional design makes it impossible to confirm this; confirmation can only be achieved by long-term research. Longitudinalexperimental studies are needed to assess the effect of running on the mechanisms involved in maintaining urinary continence.

\section{CONCLUSION}

Although few women reported experiencing UI while running, the results suggest that $\mathrm{SI}$ is present and needs to be addressed, especially when associated with risk factors such as high BMI, a large infant and episiotomy. Less time involved in running was associated with UI. Longitudinal studies should be conducted to assess pelvic floor adaptation to time engaged in physical activity as well as running. 


\section{FUNDING}

No specific grant from funding agencies in the public, commercial, or not-for-profit sectors supported the publication of this study.

\section{CONFLICTS OF INTEREST} interest.

The authors declare that they have no conflict of

\section{REFERENCES}

Abitteboul Y, Leonard F, Mouly L, Riviere D, Oustric S. Incontinence urinaire chez des coureuses de loisir de marathon. Prog Urol. 2015;25(11):636-41. http://dx.doi. org/10.1016/j.purol.2015.05.009. PMid:26159054.

Almeida MBA, Barra AA, Saltiel F, Silva-Filho AL, Fonseca AMRM, Figueiredo EM. Urinary incontinence and other pelvic floor dysfunctions in female athletes in Brazil: a cross-sectional study. Scand J Med Sci Sports. 2016;26(9):1109-16. http:// dx.doi.org/10.1111/sms.12546. PMid:26369504.

Almousa $S$, van Loon AB. The prevalence of urinary incontinence in nulliparous female sportswomen: a systematic review. J Sports Sci. 2019;37(14):1663-72. http://dx.doi.org/10.108 0/02640414.2019.1585312. PMid:30822258.

Blomquist JL, Muñoz A, Carroll M, Handa VL. Association of delivery mode with pelvic floor disorders after childbirth. JAMA. 2018;320(23):2438-47. http://dx.doi.org/10.1001/ jama.2018.18315. PMid:30561480.

$\mathrm{B} \varnothing \mathrm{K}$, Nygaard IE. Is physical activity good or bad for the female pelvic floor? A narrative review. Sports Med. 2020;50(3):471-84. http://dx.doi.org/10.1007/s40279019-01243-1. PMid:31820378.

Cândido FJ, Matnei T, Galvão LC, Santos VL, Santos MC, Sarris $A B$, et al. Incontinência urinária em mulheres: breve revisão de fisiopatologia, avaliação e tratamento. Visão Acadêmica. 2017;18(3):67-80. http://dx.doi.org/10.5380/ acd.v18i3.54506.

Casey EK, Temme K. Pelvic floor muscle function and urinary incontinence in the female athlete. Phys Sportsmed. 2017;45(4):399-407. http://dx.doi.org/10.1080/0091384 7.2017.1372677. PMid:28845723.

Driusso P, Beleza ACS, Mira DM, Sato TO, Cavalli RC, Ferreira $\mathrm{CHJ}$, et al. Are there differences in short-term pelvic floor muscle function after cesarean section or vaginal delivery in primiparous women? A systematic review with meta-analysis. Int Urogynecol J Pelvic Floor Dysfunct. 2020;31(8):1497-506. http://dx.doi.org/10.1007/s00192020-04231-6. PMid:32062680.

Filoni E, Capato CAF, Fitz FF, Fernandes OA, Sens AS. Comparação de Esportes de alto impacto e baixo impacto em relação à incontinência urinária. VIT et Sanitas. 2015;9(1):73.

Fonseca ESM, Camargo ALM, Castro RA, Sartori MGF, Fonseca MCM, Lima GR, et al. Validação do questionário de qualidade de vida (King's Health Questionnaire) em mulheres brasileiras com incontinência urinária. Rev Bras Ginecol Obstet. 2005;27(5):235-42. http://dx.doi. org/10.1590/S0100-72032005000500002.
Forner LB, Beckman EM, Smith MD. Do women runners report more pelvic floor symptoms than women in $\mathrm{CrossFit}^{\circledR}$ ? A cross-sectional survey. Int Urogynecol J Pelvic Floor Dysfunct. 2021;32(2):295-302. http://dx.doi.org/10.1007/ s00192-020-04531-x. PMid:32955598.

Haylen BT, De Ridder D, Freeman RM, Swift SE, Berghmans B, Lee J, et al. An International Urogynecological Association (IUGA)/International Continence Society (ICS) joint report on the terminology for female pelvic floor dysfunction. Neurourol Urodyn. 2010;29(1):4-20. http://dx.doi. org/10.1002/nau.20798. PMid:19941278.

Henkes DF, Fiori A, Carvalho JAM, Tavares KO, Frare JC. Incontinência urinária: o impacto na vida de mulheres acometidas e o significado do tratamento fisioterapêutico. Semin Cienc Biol Saude. 2015;36(2):57-66.

Jiang H, Qian X, Carroli G, Garner P. Selective versus routine use of episiotomy for vaginal birth. Cochrane Database Syst Rev. 2017;2:CD000081. http://dx.doi.org/10.1002/14651858. CD000081.pub3. PMid:28176333.

Keag OE, Norman JE, Stock SJ. Long-term risks and benefits associated with cesarean delivery for mother, baby, and subsequent pregnancies: systematic review and metaanalysis. PLoS Med. 2018;15(1):e1002494. http://dx.doi. org/10.1371/journal.pmed.1002494. PMid:29360829.

Lamerton TJ, Torquati L, Brown WJ. Overweight and obesity as major, modifiable risk factors for urinary incontinence in young to mid-aged women: a systematic review and meta-analysis. Obes Rev. 2018;19(12):1735-45. http:// dx.doi.org/10.1111/obr.12756. PMid:30230164.

Leitner M, Moser H, Eichelberger P, Kuhn A, Radlinger L. Evaluation of pelvic floor muscle activity during running in continent and incontinent women: an exploratory study. Neurourol Urodyn. 2017;36(6):1570-6. http://dx.doi. org/10.1002/nau.23151. PMid:27794169.

Lima CTS, Brito GA, Karbage SAL, Bilhar APM, Grande AJ, Carvalho FHC, et al. Pelvic floor ultrasound finds after episiotomy and severe perineal tear: systematic review and meta-analysis. J Matern Fetal Neonatal Med. 2020;0(0):112. http://dx.doi.org/10.1080/14767058.2020.1786049. PMid:32660290.

Martins LA, Santos KM, Dorcínio MBA, Alves JO, Roza T, Luz SCT. A perda de urina é influenciada pela modalidade esportiva ou pela carga de treino? Uma revisão sistemática. Rev Bras Med Esporte. 2017;23(1):73-7. http://dx.doi. org/10.1590/1517-869220172301163216.

Mattos TRL, Matsuoka PK, Baracat EC, Haddad JM. Urinary incontinence in female athletes: a systematic review. Int Urogynecol J Pelvic Floor Dysfunct. 2018;29(12):175763. http://dx.doi.org/10.1007/s00192-018-3629-z. PMid:29552736.

Mesquita TO, Muniz FLV, Santos KEL, Sampaio MM, Vasconcellos AAP, Nogueira IB. Prevalêcia de incontinência urinária e fatores associados em mulheres no climatério em uma unidade de atenção primária à saúde. Rev Bras em Promoção da Saúde. 2015;28(4):606-12. http://dx.doi. org/10.5020/18061230.2015.p606.

Moser H, Leitner M, Baeyens JP, Radlinger L. Pelvic floor muscle activity during impact activities in continent and 
incontinent women: a systematic review. Int Urogynecol J Pelvic Floor Dysfunct. 2018;29(2):179-96. http://dx.doi. org/10.1007/s00192-017-3441-1. PMid:28884367.

Nascimento GA, Pinto KR, Sousa VM. Avaliação da capacidade funcional inerente a dor de gestantes em atendimento fisioterapêutico na Associação Beneficente Santa Paulina de Lins [monografia]. Lins: Centro Universitário Católico Salesiano; 2017 [cited 2020 Oct 26]. Available from: http:// www.unisalesiano.edu.br/biblioteca/monografias/61017. pdf

Novo R, Perez-Rios M, Santiago-Pérez MI, Butler H, Malvar A, Hervada X. Prevalence and associated risk factors of urinary incontinence and dyspareunia during pregnancy and after delivery. Eur J Obstet Gynecol Reprod Biol. 2020;245:4550. http://dx.doi.org/10.1016/j.ejogrb.2019.10.020. PMid:31851895.

Nygaard IE, Shaw JM. Physical activity and the pelvic floor. Am J Obstet Gynecol. 2016;214(2):164-71. http://dx.doi. org/10.1016/j.ajog.2015.08.067. PMid:26348380.

Pedersen LS, Lose G, Høybye MT, Elsner S, Waldmann A, Rudnicki $M$. Prevalence of urinary incontinence among women and analysis of potential risk factors in Germany and Denmark. Acta Obstet Gynecol Scand. 2017;96(8):939-48. http:// dx.doi.org/10.1111/aogs.13149. PMid:28401541.

Pires T, Pires P, Moreira H, Gabriel R, Viana S, Viana R. Assessment of pelvic floor muscles in sportswomen: quality of life and related factors. Phys Ther Sport. 2020;43:151-6. http:// dx.doi.org/10.1016/j.ptsp.2020.02.015. PMid:32200260.
Pizzol D, Demurtas J, Celotto S, Maggi S, Smith L, Angiolelli $G$, et al. Urinary incontinence and quality of life: a systematic review and meta-analysis. Aging Clin Exp Res. 2021;33(1):25-35. http://dx.doi.org/10.1007/s40520-02001712-y. PMid:32964401.

Shaw JM, Nygaard IE. Role of chronic exercise on pelvic floor support and function. Curr Opin Urol. 2017;27(3):257-61. http://dx.doi.org/10.1097/MOU.0000000000000390. PMid:28212118.

Silva JPC, Soler ZGSA, Wysochi AD. Fatores associados à incontinência urinária em mulheres submetidas ao exame urodinâmico. Esc Enferm USP. 2017;51:e03209.

Tamanini JT, Dambros M, D'Ancona CA, Palma PC, Rodrigues Netto N Jr. Validação para o português do "International Consultation on Incontinence Questionnaire-Short Form" (ICIQ-SF). Rev Saude Publica. 2004;38(3):438-44. http://dx.doi.org/10.1590/S0034-89102004000300015. PMid:15243675.

Teixeira RV, Colla C, Sbruzzi G, Mallmann A, Paiva LL. Prevalence of urinary incontinence in female athletes: a systematic review with meta-analysis. Int Urogynecol J Pelvic Floor Dysfunct. 2018;29(12):1717-25. http://dx.doi. org/10.1007/s00192-018-3651-1. PMid:29654349.

Vasaghi-Gharamaleki B, Ostad-Rahimi S. Preliminary study on prevalence of urinary incontinence in iranian female athletes. Int J Sport Exerc Med. 2015;1(5):1-4. http:// dx.doi.org/10.23937/2469-5718/1510028. 